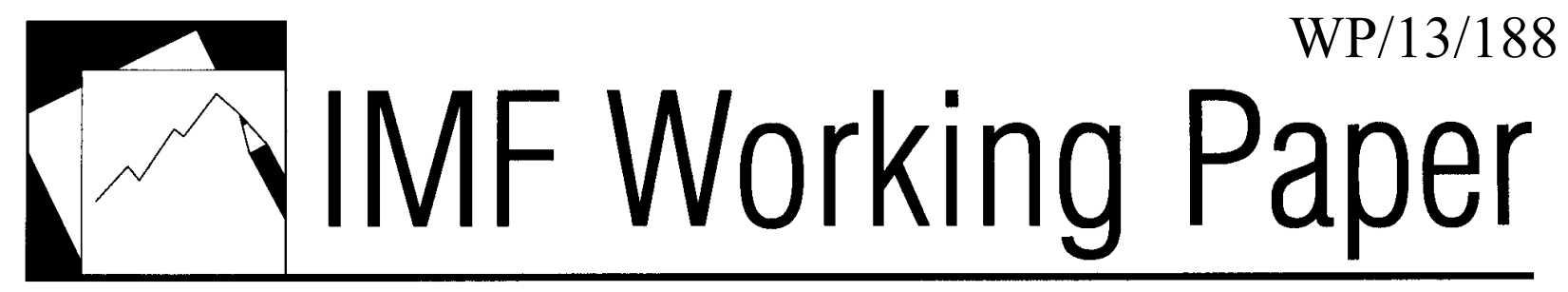

\title{
Resource Dependence and Fiscal Effort in Sub-Saharan Africa
}

Alun Thomas and Juan P. Treviño 


\title{
IMF Working Paper
}

\author{
African Department
}

\author{
Resource Dependence and Fiscal Effort in Sub-Saharan Africa \\ Prepared by Alun Thomas and Juan P. Treviño* \\ Authorized for distribution by Alfredo Cuevas
}

August 2013

\begin{abstract}
This Working Paper should not be reported as representing the views of the IMF. The views expressed in this Working Paper are those of the author(s) and do not necessarily represent those of the IMF or IMF policy. Working Papers describe research in progress by the author(s) and are published to elicit comments and to further debate.
\end{abstract}

\begin{abstract}
High natural resource prices in recent years have resulted in sizeable increases in fiscal revenue for many resource-exporting countries in sub-Saharan Africa. However, this revenue source is volatile, and arguably these countries should also rely on other forms of taxation to help fund public expenditure. This paper asks whether the availability of higher resource revenue in these countries has led to lower taxation effort of other revenue categories. The question is analyzed both in terms of the relationship between non-resource tax revenue and resource revenue, and between non-resource tax revenue and statutory tax rates. The paper finds evidence suggesting that nonresource revenue is negatively influenced by a higher resource revenue-to-GDP ratio. The lower take up of nonresource taxes in resource-rich countries is correlated with higher levels of corruption in these countries, suggesting weaker institutions affect nonresource revenue through incentives for tax evasion and/or large tax exemptions as argued in the literature.
\end{abstract}

JEL Classification Numbers: H10, H2, H20, H30, H50, Q30, Q33, Q38

Keywords: Tax law, taxation, exhaustible resources, resource rich, oil, resource booms Authors’ E-Mail Addresses: athomas@imf.org; jtrevino@imf.org

\footnotetext{
* An earlier version of this paper was presented at the Centre for the Study of African Economies at Oxford University. The authors would like to thank, without implication, Montfort Mlachila, Chris Adam, Paulo Drummond, Joel Toujas-Bernate, and Atsushi Oshima for useful comments and suggestions and Jenny Kletzin DiBiase for editorial assistance. All remaining errors are those of the authors.
} 


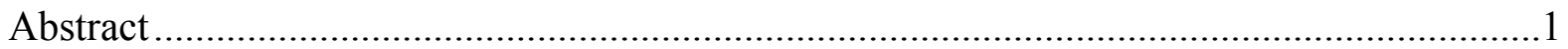

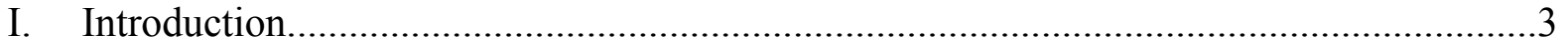

II. Revenue and Expenditure Aggregates in Sub-Saharan Africa .....................................

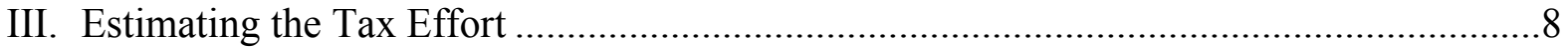

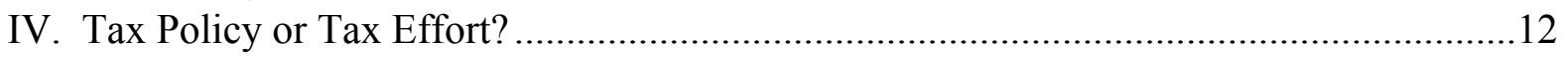

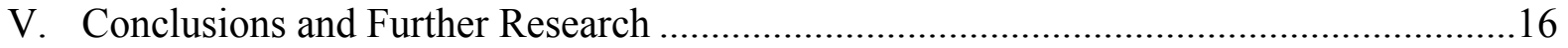

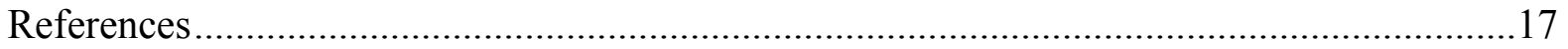

Tables

1. Tax Effort Panel Regression Results ........................................................................10

2. Effect of Statutory Tax Rates on Nonresource Revenue ...........................................15

Figures

1. Resource Exports ....................................................................................................

2. Resource Revenue in Resource-Intensive Countries ...................................................5

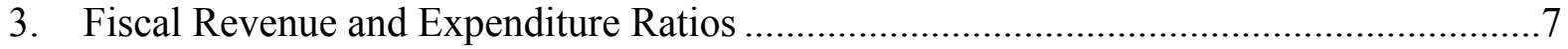

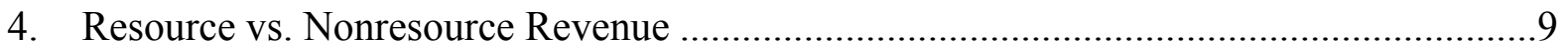

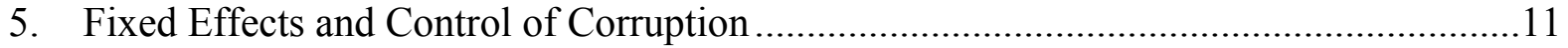

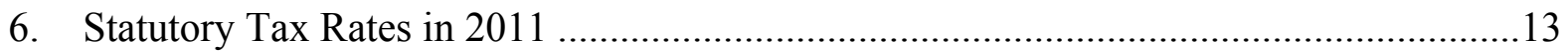

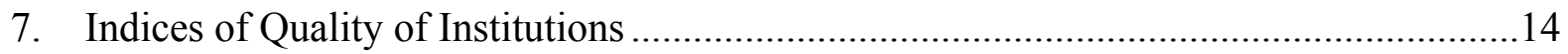

\section{Boxes}

1. Non-Renewable Natural Resources in Sub-Saharan Africa ......................................6 


\section{INTRODUCTION}

High resource prices in recent years have resulted in sizeable increases in fiscal revenue for countries that collect revenue from natural resources. However, this revenue source is volatile and resource countries must also rely on other forms of taxation to help fund public expenditure. With needs for improved health services and requests for better quality and more advanced education in many of these countries, the demands on available revenue sources are becoming ever more pressing. In this context, this paper asks whether the availability of higher resource revenue leads to a lower taxation effort of other revenue categories. This question is analyzed both in terms of the relationship between non-resource tax revenue and resource revenue, and between non-resource tax revenue and statutory tax rates.

The determinants of tax revenue ratios have been extensively analyzed over the past three decades. Seminal studies such as Tanzi $(1987,1992)$ explored the role of foreign debt in the variation of tax ratios in developing countries, while Leuthold (1991) analyzed the importance of development in the determination of tax shares in Africa. These studies included the sectoral composition of output as additional determinants of the tax ratios. Stotsky and WoldeMariam (1997) and Ghura (1998) confirmed Tanzi's finding that in developing countries half of the variation in tax ratios is explained by development (per

capita income) and import and agriculture shares, but found no evidence that foreign debt played a role.

Following the earlier approach, more recent work by Gupta (2007), Davoodi and Grigorian (2007), and others supports the view that per capita income, the share of agriculture GDP, and the degree of trade openness are main determinants of tax ratios. These studies have also incorporated foreign aid flows and institutional factors (especially corruption) as explanatory variables. Intuitively, foreign aid represents a relatively costless windfall that could become a substitute for domestic revenue (Bräutigam, 2000), while poor quality of institutions may induce tax evasion and (resource) rent-seeking (Tanzi and Davoodi, 1997; Collier, 2005). While the effect of foreign aid is not consistently negative in empirical research (Gupta and others, 2003; Drummond, Srivastava, and Oliveira, 2012), the adverse effect of corruption on revenue is more widely supported empirically (Davoodi and Grigorian, 2007; Bird, MartinezVazquez, and Torgler, 2008; Bornhorst, Gupta, and Thornton, 2009; and Drummond, Srivastava, and Oliveira, 2012).

This paper focuses explicitly on whether countries with higher resource revenue tend to receive lower taxation revenue from other forms of income and consumption expenditure. The literature about this issue is fairly scant, but evidence suggests that higher resource rents (revenue) lead to significantly lower (nonresource) tax revenue, holding other factors constant. Morrison (2005), for example, has found that the elasticity of income tax revenue with respect to nontax revenue (royalties and foreign aid) is negative $(-0.05)$ and significant 
for countries with dictatorships but insignificant in democracies. Bornhorst, Gupta, and Thornton (2009) document a negative coefficient as well (ranging from -0.15 to -0.43 ). Drummond, Srivastava, and Oliveira (2012) also find that the effect of resource rents on the tax ratio is negative (ranging from -0.1 for oil to -0.18 for other natural resources).

We find evidence suggesting that non-resource revenue ratios are negatively influenced by higher ratios of resource revenue to GDP. A novel finding of the paper is that the lower take up of nonresource taxes in resource-rich countries is correlated with higher levels of corruption in those countries rather than any differences in statutory tax rates. This suggests that nonresource revenue in resource-rich countries is affected by incentives for tax evasion, large tax exemptions, and/or weaker enforcement.

The rest of the paper is organized as follows. Section II describes the data and presents country-specific characteristics. Following work by Bornhorst, Gupta, and Thornton (2009), Section III presents panel regression estimations of the determinants of nonresource revenue for a group of 42 countries in sub-Saharan Africa (SSA) between 2000 and 2011. Section IV looks at whether panel regression results reflect lower tax effort (tax evasion) or optimal tax policy actions. Section $\mathrm{V}$ concludes and discusses possible extensions to the analysis.

\section{ReVEnUE AND EXPENDITURE AgGREgATES IN SUb-SAHARAN AfRICA}

The revenue and expenditure data for this analysis comes from a database set up in the African Department of the International Monetary Fund (IMF) that includes all SSA economies, except South Sudan (Box 1). The database separates resource revenue and nonresource revenue by country and is available for $2000-11 .^{2}$ Resource revenue data is used for a subgroup of 20 countries deemed "resource intensive" in the region, defined as those countries where natural resource exports exceeded 25 percent of total merchandise exports in 2005-10 (Figure 1). ${ }^{3}$

Among the resource-intensive countries, 10 are deemed "fiscally dependent" on natural resources (Figure 2) because in these countries revenue from natural resources exceeded 20 percent of budgetary revenue in the same period. Oil exporters derive most of their revenue from natural resources, with the share of budgetary revenue from oil receipts varying between 90 percent (Equatorial Guinea) to slightly below 60 percent (Gabon). The same countries generally have the highest ratios in terms of resource exports. The countries with the lowest share of budgetary receipts from natural resources in 2005-10 were Ghana, Sierra Leone, South Africa, and Tanzania at less than 5 percent of total revenue.

\footnotetext{
${ }^{2}$ Resource revenue may not cover all revenue accruing to the state from the extraction of natural resources because corporate tax payments of resource companies are not always separated out.

${ }^{3}$ See IMF (2012).
} 
Figure 1. Resource Exports

(average 2005-10)

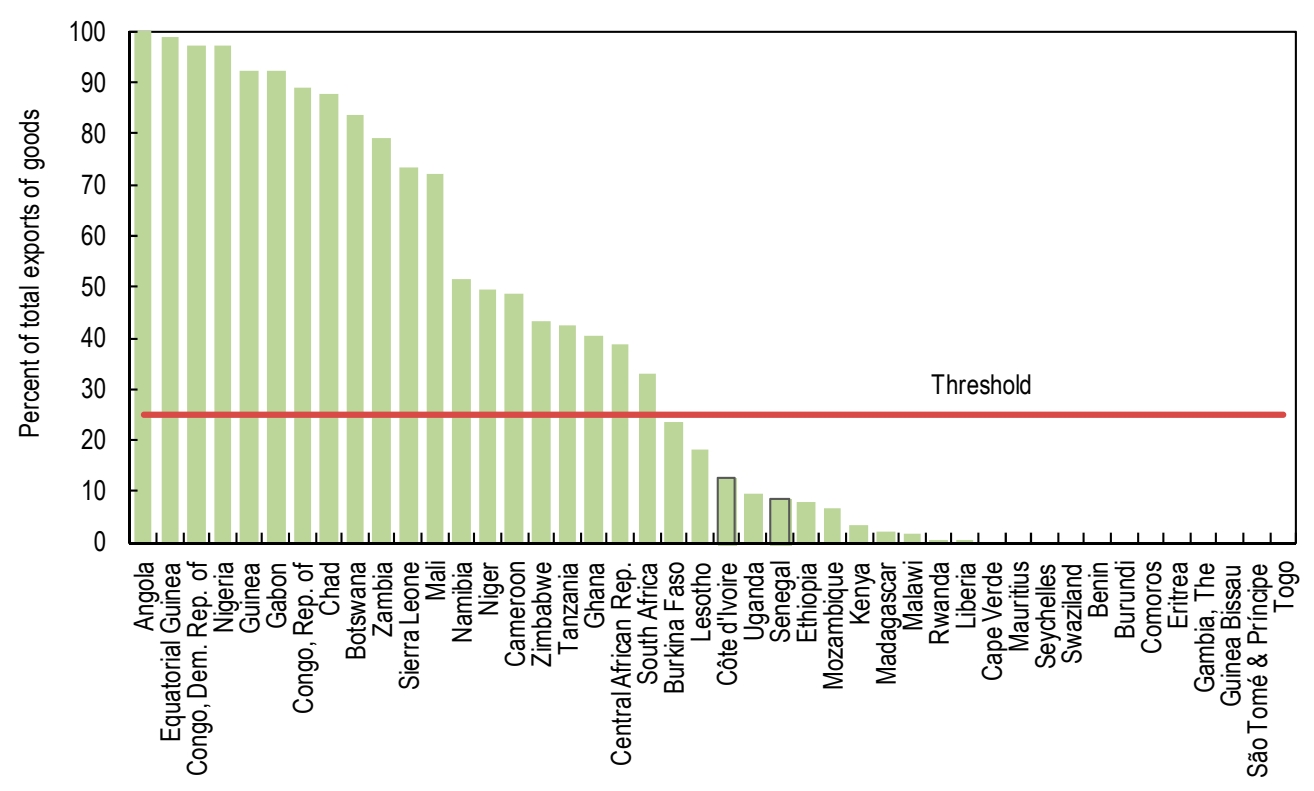

Source: IMF African Department Database.

*Data for Côte d'Ivoire and Senegal excludes re-exports of refined oil products.

Figure 2. Resource Revenue in Resource-Intensive Countries

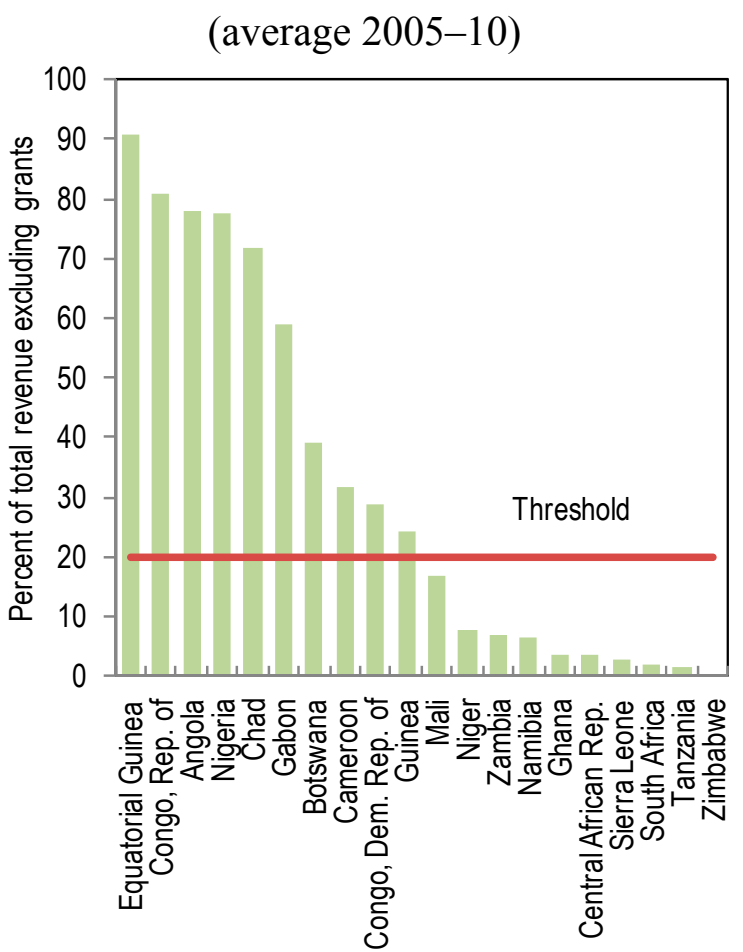

Source: IMF African Department database. 


\section{Box 1: Non-Renewable Natural Resources in Sub-Saharan Africa}

Nearly 10 percent of the annual output of sub-Saharan African (SSA) countries and 50 percent of their exports come from non-renewable natural resources. Natural resources are a major export in about 20 of the 45 countries in the region. Seven of these countries are oil exporters, accounting for more than half of the region's natural resource exports. The other 13 resource-rich economies receive at least a quarter of their export proceeds from mining.

Gold, diamonds, and other precious stones are the major commodity exports of most of the region's non-oil resource-rich economies. A few, however, depend heavily on base metals and uranium (Niger, Zambia) or benefit from a broad mixture of products (the Democratic Republic of the Congo, Guinea, Namibia, Sierra Leone).

Given wide variations in the costs of exploiting different non- renewable resources and in the ability of tax regimes to harness the associated rents, government revenue from natural resource exploitation differs substantially among countries. While much of this analysis focuses on the 20 natural resource exporters in the region, special attention is paid to the 10 economies deemed fiscally dependent on natural resources.

Some countries currently listed as nonresource-rich nonetheless have significant resource export potential. For instance, Mozambique, Sāo Tomé and Príncipe, and Uganda are among several countries seeking to exploit oil and gas reserves; prospects for offshore oil deposits in Liberia look promising; and Malawi has potentially large uranium deposits. Some resource exporters, such as Ghana (oil), Sierra Leone (iron ore), and Tanzania (gas) are also broadening the spectrum of their commodity exports. As Collier (2011) has pointed out, it is likely that the bulk of exploitable natural resources remain to be revealed, because the identified level of such resources in the region is currently far below that of other areas.

Source: IMF (2012)

There is a large difference in the revenue share in terms of nonresource output for fiscally dependent countries and other resource and nonresource countries in SSA (Figure 3, top panel). Revenue in relation to nonresource output for the fiscally dependent countries has averaged about 50 percent in the past decade with large variations associated with movements in natural resource prices. In contrast, the revenue ratios for the other resource and nonresource countries have been stable during the period, averaging about 20 percent of nonresource output. The revenue ratio for resource-intensive countries outside SSA is comparable to the profile for SSA.

In terms of nonresource revenues, these are more stable than total revenues for the fiscally dependent countries (Figure 3, center panel). These countries receive less nonresource revenue than the other countries in the region, but the difference is much less than for total 
revenue so that aggregate revenue collection is much higher. Some of these differences may not only be related to the large amount of revenue gleaned from resources, but could also reflect other factors. For example, according to the Kaufmann and Kraay index, Cape Verde and Equatorial Guinea have the lowest and highest levels of corruption among SSA economies, respectively. At the same time, the difference in non-resource revenue ratios between these two countries is quite sizable at about 6 percentage points in 2000-11. This raises the question whether corruption can explain differences in nonresource revenue across countries, which we explore below.

Higher revenue translates into higher expenditure for the fiscally dependent group, and this is also true of the experiences of resource-rich countries outside SSA (Figure 3, bottom panel). Interestingly, little difference is shown between the non-resource revenue ratio of the resource countries that are not fiscally dependent and nonresource countries. This suggests that for this group of resource countries, the availability of natural resources has had little effect on resource revenue partly because they collect little resource revenue.

For resource-rich countries outside of $\mathrm{SSA}$, the non-resource revenue ratio is considerably higher than for SSA countries, and perhaps surprisingly, the revenue ratio fluctuates in line with the development of resource
Figure 3. Fiscal Revenue and Expenditure Ratios, 2000-11 (Unweighted avergage)
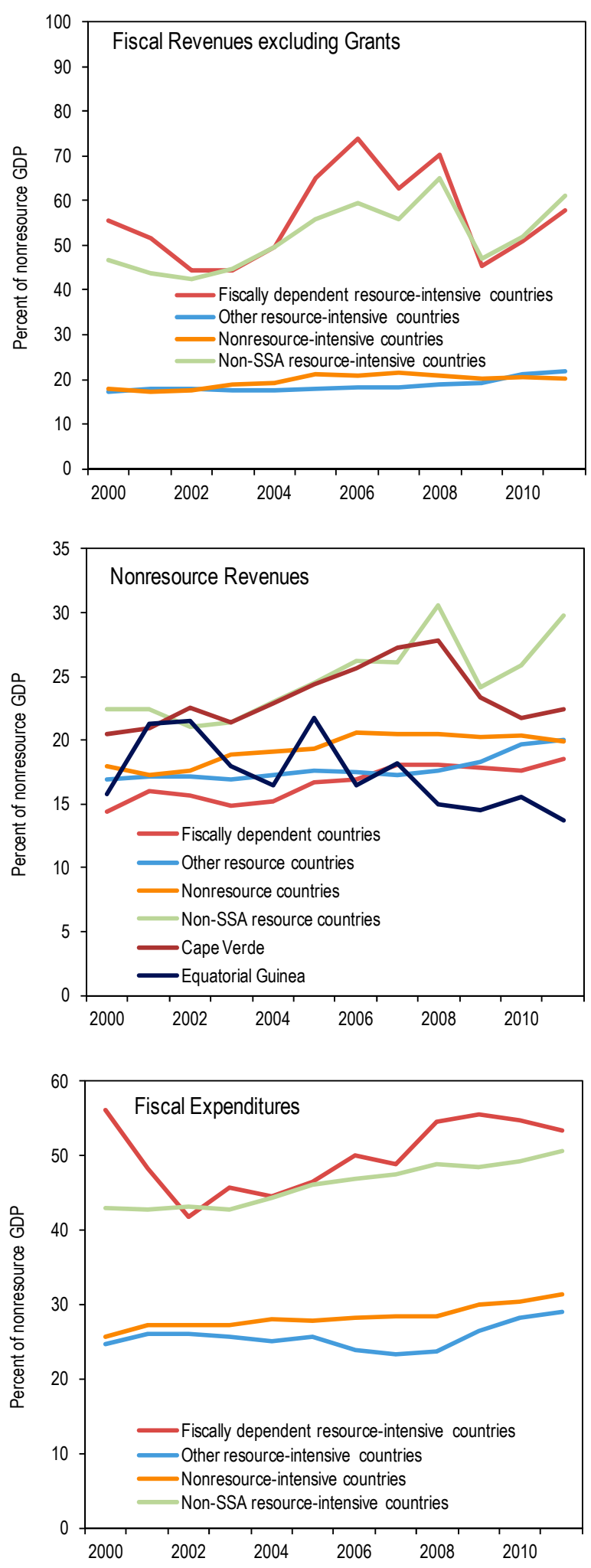

Sources: IMF, African Department database; and IMF, Strategy, Policy, and Review Department survey data. 
prices. This suggests that linkages between the resource and nonresource sectors are very strong outside SSA.

\section{Estimating THE TAX EFFORT}

A first look at the data yields a negative and significant correlation between resource and non-resource fiscal revenue among resource-rich countries in SSA (Figure 4). To explore some of these issues further, a panel regression of the determinants of nonresource revenue is estimated for SSA between 2000 and 2011 (excluding South Sudan), following Bornhorst, Gupta, and Thornton (2009). Specifically, the regression takes the form

$$
\left(\frac{N R R}{Y}\right)_{i t}=\alpha_{i}+\beta\left(\frac{R R}{Y}\right)_{i t}+\gamma \text { controls }_{i t}+u_{i t}
$$

where $\left(\frac{N R R}{Y}\right)_{i t}$ and $\left(\frac{R R}{Y}\right)_{i t}$ denote the ratios of nonresource revenue and resource revenue to GDP for country $i$ at time $t$, respectively. Controls include foreign aid (measured by the grants-to-GDP ratio), the level of income (measured by the log of real per capita GDP), openness to international trade (exports plus imports to GDP), the output share of agriculture, the urban population share, and a corruption index from the International Country Risk Guide (ICRG). ${ }^{4}$ In the regression all countries are included (with $R R$ equal to 0 for nonresource exporters) and we allow for country-specific fixed effects.

The choice of denominator for the regression is not a trivial issue because we do not want the denominator to contaminate the analysis. As mentioned previously, it is difficult to fully isolate nonresource revenue because of difficulties in isolating the resource and non-resource revenue streams of corporate taxation. Therefore, choosing total GDP over nonresource GDP as the standardizing variable has some support and it has been heavily used in the literature. However, the results are sensitive to the choice of denominator (see below).

\footnotetext{
${ }^{4}$ The International Country Risk Guide (ICRG) rating comprises 22 variables in three subcategories of risk: political, financial, and economic. A separate index is created for each of the subcategories. The Political Risk index is based on 100 points, Financial Risk on 50 points, and Economic Risk on 50 points. The total points from the three indices are divided by two to produce the weights for inclusion in the composite country risk score. The composite scores, ranging from zero to 100, are then broken into categories from Very Low Risk (80 to 100 points) to Very High Risk (zero to 49.9 points). See http://www.prsgroup.com/icrg.aspx.
} 
Figure 4. Resource vs. Nonresource Revenue

(average 2000-11)

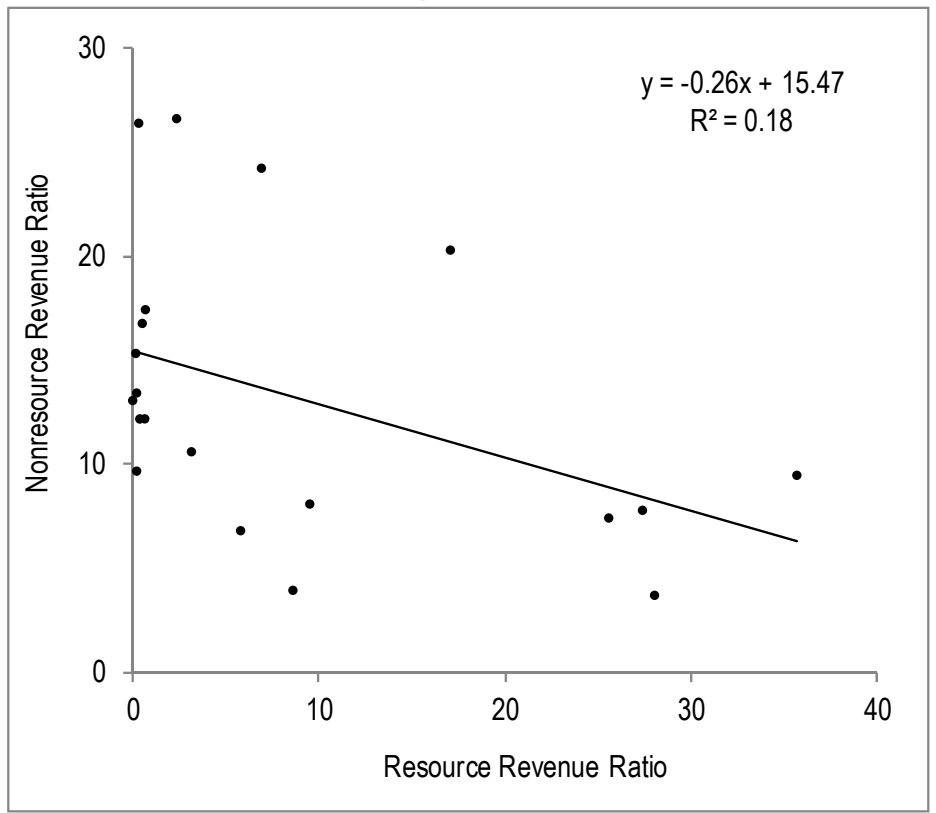

Source: Authors' calculations; IMF African Department Database.

As shown in Table 1 (columns 1 and 2), the coefficient associated with resource revenue ( $\beta$ in the equation above) is negative and significant. ${ }^{5}$ In particular, the contemporaneous estimation (column 1) implies that a 1 percent increase in resource revenue reduces nonresource revenue by 0.12 percentage point. The effect decreases to 0.07 when including the lag of the dependent variable on the right-hand side (column 2), which itself is positive and significant, consistent with the finding elsewhere that revenue ratios are persistent over time. The latter implies that over the long run, the cumulative impact would be -0.15 and comparable to the initial estimate without the dynamic component. Interestingly, when including the lags of both the resource and non-resource revenue-to-GDP ratios as regressors (column 4), only the latter is positive and significant.

\footnotetext{
${ }^{5}$ All specifications include country dummy variables unless specified otherwise.
} 
Table 1. Tax Effort Panel Regression Results

\begin{tabular}{|c|c|c|c|c|c|c|c|c|}
\hline \multicolumn{9}{|c|}{ Dep. Var.: Nonresource Revenue Ratio } \\
\hline & (1) & $(2)$ & (3) & $(4)$ & $(5)^{1 /}$ & $(6)^{1 / 2 /}$ & $(7)^{3 /}$ & (8) \\
\hline \multirow[t]{2}{*}{ constant } & $-0.15^{* * *}$ & $-0.07^{* * *}$ & $-0.17^{* * *}$ & -0.03 & $-0.37^{* * *}$ & $-0.28^{* * *}$ & $-0.14^{\star * *}$ & $-0.05^{* \star}$ \\
\hline & $(0.02)$ & $(0.02)$ & $(0.02)$ & $(0.02)$ & $(0.12)$ & $(0.03)$ & $(0.02)$ & $(0.02)$ \\
\hline \multirow[t]{2}{*}{ Resource Revenue Ratio } & $-0.12^{* * *}$ & $-0.07^{* * *}$ & & & -0.34 & 0.06 & $-0.11^{* * *}$ & $-0.10^{* * *}$ \\
\hline & $(0.03)$ & $(0.01)$ & & & $(0.21)$ & $(0.16)$ & $(0.03)$ & $(0.03)$ \\
\hline \multirow[t]{2}{*}{ Resource Revenue Ratio (lag) } & & & $-0.08^{* *}$ & 0.04 & & & & \\
\hline & & & $(0.03)$ & $(0.03)$ & & & & \\
\hline \multirow[t]{2}{*}{ Nonresource Revenue Ratio (lag) } & & $0.54^{\star * *}$ & & $0.58^{\star * *}$ & & & & \\
\hline & & $(0.04)$ & & $(0.05)$ & & & & \\
\hline \multirow[t]{2}{*}{ Grants } & $-0.02^{* *}$ & $-0.02^{* *}$ & $-0.02^{* *}$ & $-0.02^{* *}$ & 0.11 & 0.11 & $-0.02^{* *}$ & $-0.02^{*}$ \\
\hline & $(0.01)$ & $(0.01)$ & $(0.01)$ & $(0.01)$ & $(0.16)$ & $(0.15)$ & $(0.01)$ & $(0.01)$ \\
\hline \multirow[t]{2}{*}{ Real Per-Capita GDP } & $0.02^{* * *}$ & $0.01^{* * *}$ & $0.02^{* * *}$ & 0.00 & $0.06^{* *}$ & $0.03^{* * *}$ & $0.02^{* * *}$ & $0.02^{* * *}$ \\
\hline & $(0.00)$ & $(0.00)$ & $(0.00)$ & $(0.01)$ & $(0.03)$ & $(0.01)$ & $(0.00)$ & $(0.00)$ \\
\hline \multirow[t]{2}{*}{ Trade Openness } & $0.05^{\star *}$ & $0.09^{* * *}$ & $0.14^{* * *}$ & $0.08^{* *}$ & $0.46^{* * *}$ & $0.55^{\star * *}$ & $0.05^{\star *}$ & $0.05^{* *}$ \\
\hline & $(0.02)$ & $(0.03)$ & $(0.03)$ & $(0.04)$ & $(0.13)$ & $(0.11)$ & $(0.02)$ & $(0.03)$ \\
\hline \multirow[t]{2}{*}{ Share of Agriculture } & $-0.08^{* *}$ & -0.04 & -0.05 & -0.02 & -0.10 & $-0.23^{* * *}$ & $-0.08^{* *}$ & $-0.05^{*}$ \\
\hline & $(0.03)$ & $(0.03)$ & $(0.03)$ & $(0.03)$ & $(0.09)$ & $(0.07)$ & $(0.03)$ & $(0.03)$ \\
\hline \multirow[t]{2}{*}{ Share of Urban Population } & $0.01^{* * *}$ & $0.00^{* * *}$ & $0.01^{* * *}$ & $0.00^{* * *}$ & $0.01^{* * *}$ & $0.01^{* * *}$ & $0.01^{* * *}$ & $0.01^{* * *}$ \\
\hline & $(0.00)$ & $(0.00)$ & $(0.00)$ & $(0.00)$ & $(0.00)$ & $(0.00)$ & $(0.00)$ & $(0.00)$ \\
\hline \multirow[t]{2}{*}{ Corruption (control of) } & $0.02^{* * *}$ & $0.01^{* * *}$ & $0.02^{* * *}$ & $0.01^{* * *}$ & $0.03^{*}$ & $0.02^{*}$ & $0.02^{* * *}$ & $0.02^{* * *}$ \\
\hline & $(0.00)$ & $(0.00)$ & $(0.00)$ & $(0.00)$ & $(0.02)$ & $(0.01)$ & $(0.00)$ & $(0.00)$ \\
\hline \multirow[t]{2}{*}{ Resource Revenue Ratio*other } & & & & & & & $-0.61^{* * *}$ & \\
\hline & & & & & & & $(0.17)$ & \\
\hline \multirow[t]{2}{*}{ Real Effective Exchange Rate } & & & & & & & & $-0.03^{* * *}$ \\
\hline & & & & & & & & $(0.01)$ \\
\hline R-squared & 0.94 & 0.97 & 0.95 & 0.97 & 0.94 & 0.93 & 0.94 & 0.95 \\
\hline Sum squared resid & 0.19 & 0.09 & 0.15 & 0.09 & 0.18 & 0.25 & 0.19 & 0.16 \\
\hline Durbin-Watson Stat & 1.10 & 2.17 & 1.21 & 2.24 & 1.41 & 1.45 & 0.89 & 0.85 \\
\hline Observations & 366 & 326 & 328 & 326 & 287 & 287 & 287 & 352 \\
\hline \multicolumn{9}{|c|}{ S.E. in parentheses } \\
\hline \multicolumn{9}{|l|}{ 1/ Lagged variables are included as instruments } \\
\hline \multicolumn{9}{|c|}{${ }^{2 /}$ Dep. Var: nonresource revenue to nonresource GDP } \\
\hline 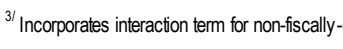 & & & & & & & & \\
\hline
\end{tabular}


The signs of other coefficients are generally consistent with the literature, except for foreign aid. Interestingly, the development of the economy as a whole (proxied by real per capita GDP) is positively and significantly associated with higher revenue (though it becomes insignificant when lags of the revenue ratios are included, column 4). Trade openness and the share of urban population each have a positive and significant effect on nonresource revenue, whereas the share of agriculture is significant only for the baseline regression (column 1). Overall, this suggests that less developed countries tend to exhibit lower revenue mobilization. By construction,

Figure 5. Fixed Effects and Control of Corruption

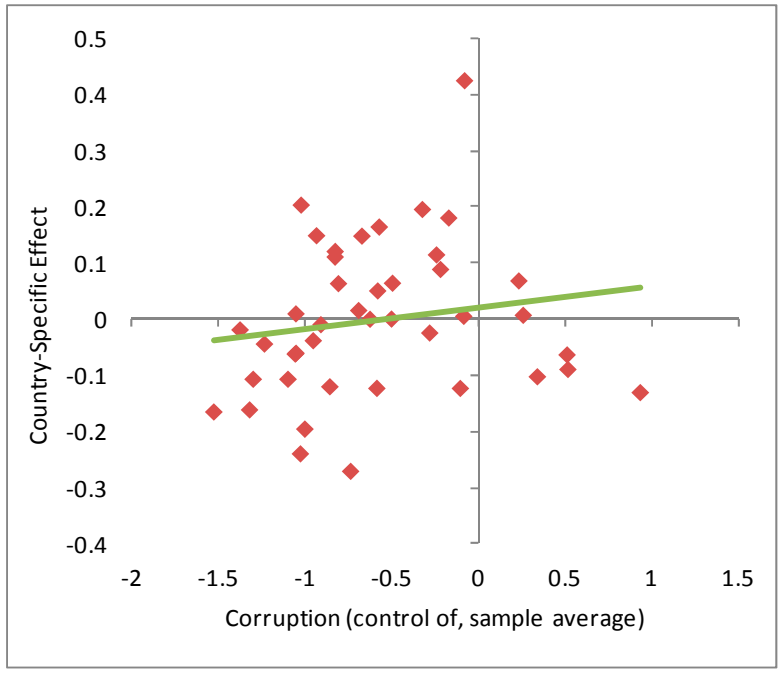

Source: Authors' estimations. the measure for corruption (ICRG) increases as corruption diminishes, hence the positive sign, with lower corruption associated with higher nonresource revenue; and the effect is robust to all specifications. ${ }^{6}$ Coming back to the example of Equatorial Guinea and Cape Verde in Section II, while statistically significant, the measure of corruption appears to explain only part of the observed difference in nonresource revenue ratios between these 2 countries (at most 1 percentage point). Note, however, that part of the effect from corruption is captured by the country-specific effect as shown in Figure 5, which depicts the correlation between the country-specific effect estimated for column (1) of Table 1 and the sample average measure of corruption (also, the coefficient for the measure of corruption doubles when not controlling for country-specific effects). A larger inflow of foreign aid (grants) in proportion to GDP has a negative effect on nonresource-related revenue mobilization with the coefficient of -0.02 implying that an additional 10 percent of GDP in grant funding reduces nonresource revenue by 0.2 percent. This effect is found to be stronger than elsewhere in the literature (in a number of studies it is insignificant).

To check for robustness of the results, we control for endogeneity using lagged variables as instruments except for the urban population, which we regard as slow-moving (column 5). In this specification, the coefficient $\beta$ remains negative but is not significant. We also estimate the basic specification using nonresource revenue to nonresource GDP as the dependent variable (because this is a closer measure of the tax base). Once again (column 6), controlling for endogeneity, the effect of resource revenue is not significant. Finally, we estimate equation (1) incorporating an interaction term for resource countries that are not fiscally dependent (countries where resource revenue is less than 20 percent of total revenue). In this

\footnotetext{
${ }^{6}$ The use of the rule of law indicator as an alternative to the corruption index is less robust because it is insignificant in specifications 2 and 4 .
} 
case, $\beta$ is negative and significant (column 7). Interestingly, the interaction coefficient is also negative and significant and larger than for the rest of the group. This suggests that countries that rely less on resource revenue actually reduce their fiscal effort more when receiving additional resource revenue. However, the absolute magnitude of the effect is considerably weaker because the resource revenue ratio is very small. ${ }^{7}$

Finally, the (log of the) real effective exchange rate is included as a regressor following Adam, Bevan, and Chambas (2000). The argument is that a real appreciation may reflect a positive wealth effect that facilitates a lower tax effort. Interestingly, this effect is present even with the inclusion of resource revenue as a separate variable (column 8). This may reflect that the resource revenue variable proxies terms of trade effects in the previous year because of lags in tax collection, whereas the real exchange rate is immediately affected by fluctuations in commodity prices. To assess whether the effects are different for resource-rich countries and other countries that are not fiscally dependent, we include an interactive term for the latter group. Under this specification, the effect of the real exchange rate cancels out for the countries that are less fiscally dependent but remains strong for the countries with high dependence on fiscal revenue.

\section{TAX POLICY OR TAX EFFort?}

The previous section shows that the ratio of nonresource revenue to nonresource output is lower in countries that receive revenue from natural resources. This is consistent with the view that countries are willing to trade off some nonresource revenue when resource revenue is abundant but not to the extent that one might initially expect. However, it has been argued that statutory tax rates differ little between resource and nonresource countries. If this is the case, the lower non-resource revenue ratio could reflect incentives for tax evasion from weak administration and/or large tax exemptions as argued by Tanzi and Davoodi (1997).

\footnotetext{
${ }^{7}$ We also use the Arellano-Bond (1991) approach to control for autocorrelation in the presence of the lagged dependent variable. In this case (regressions not shown, the coefficient $\beta$ is generally not significant.
} 
Figure 6. Statutory Tax Rates in 2011

(percent of tax base)

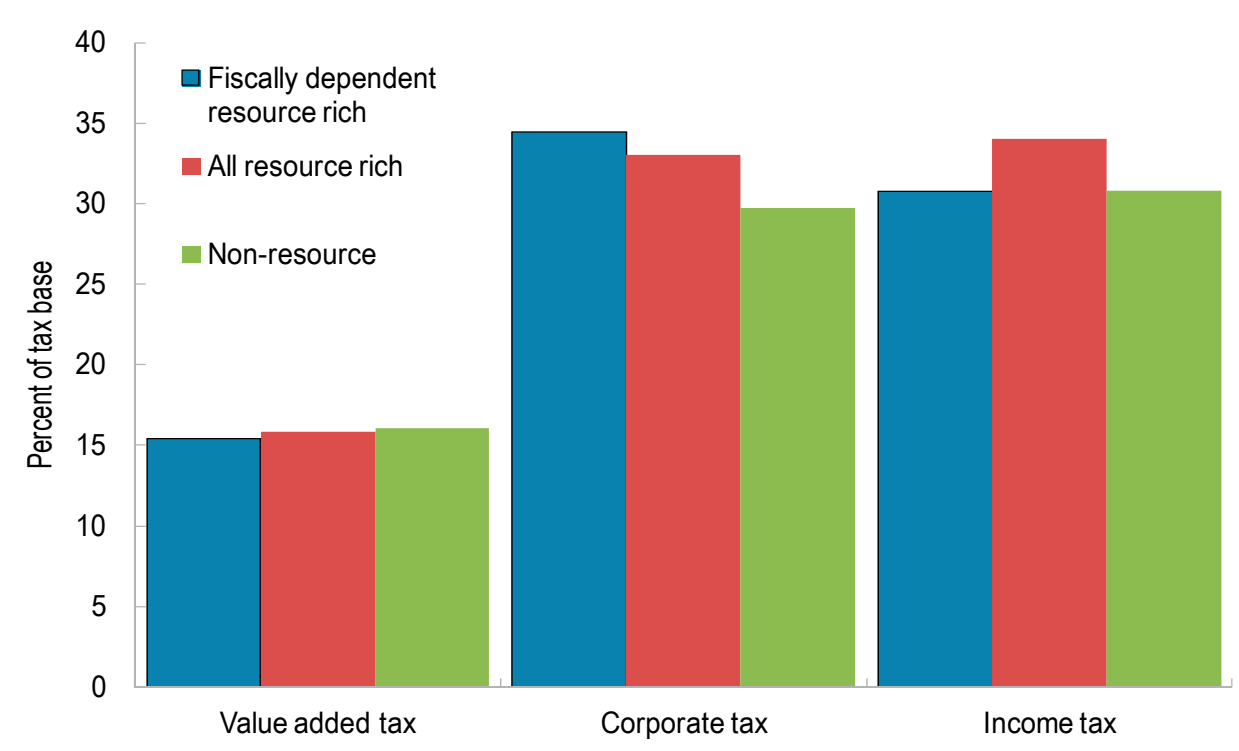

Source: IMF Fiscal Affairs Department Database.

To test whether the non-resource revenue ratio is lower in the resource countries because of tax evasion and/or large tax exemptions, we regress the non-resource revenue ratio against the statutory tax rate for value-added taxes (VAT), corporate taxes, and income taxes. The basic hypothesis is that if tax evasion and tax exemptions are absent, the coefficient on the statutory tax rate should be similar for resource-rich and resource-poor countries; whereas if these elements are present in resource-rich countries, the coefficient on the statutory tax rate would be lower for the resource-rich group. Unfortunately, the statutory tax rates are only available for one year, 2011, and therefore the analysis is purely a cross-section panel estimation. Resource countries that collect large resource revenue (fiscally dependent sample) are distinguished from other countries.

Before turning to regression analysis, we first present averages of the statutory tax rates for value-added tax, corporate tax, and income tax for three country groups: the fiscally dependent resource countries, all resource countries, and the nonresource countries of the region. Average statutory tax rates in 2011 are very similar across the three country groups (Figure 6), with the largest difference in the corporate tax rate. Indeed, the corporate tax rate is highest for the fiscally dependent group, at almost 35 percent, whereas it is 30 percent for the nonresource countries. This fact combined with the knowledge that nonresource taxes are lower in the fiscally dependent group suggests that the regression coefficient on the statutory tax rates for the fiscally dependent group is lower than for other countries. 
Figure 7. Indices of Quality of Institutions

(from 2 for "less corrupt" to -2 for "more corrupt")

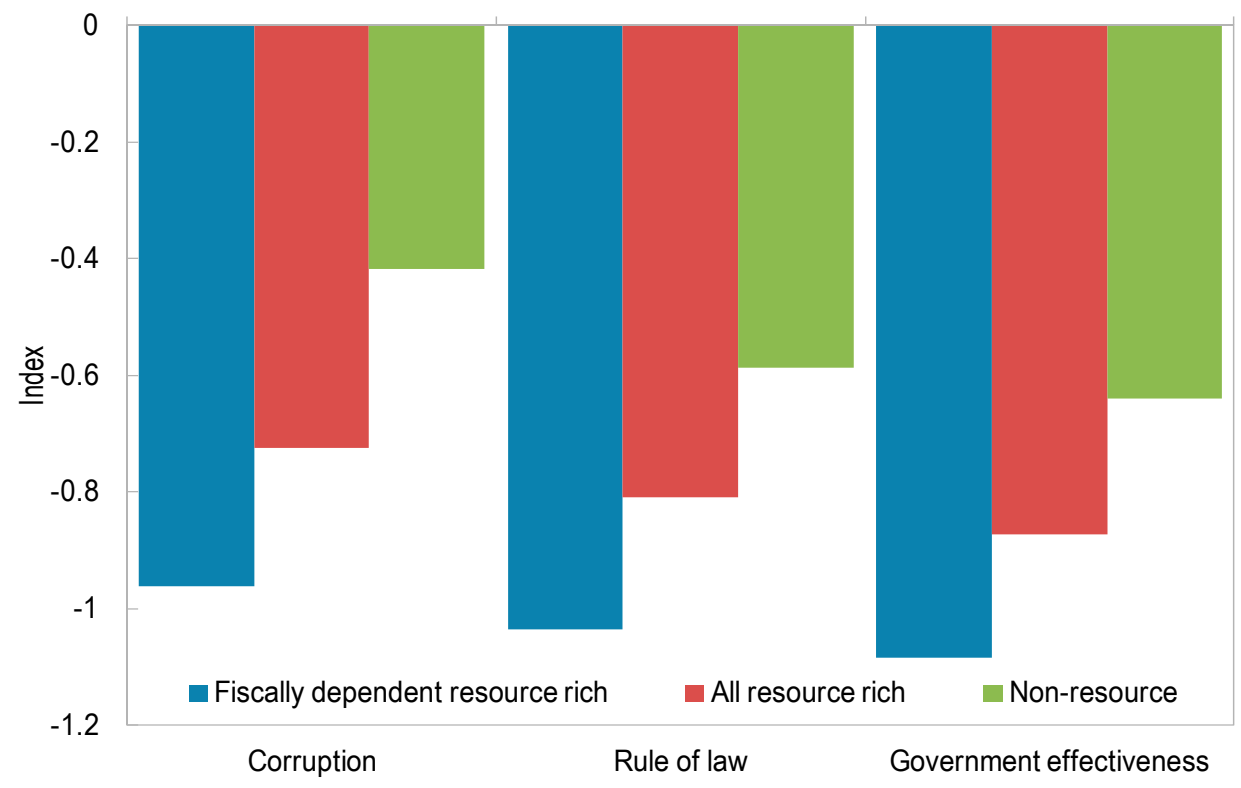

Sources: World Bank; Kauffman and Kraay Indices.

Part of the explanation for the lower level of nonresource revenue in the fiscally dependent group is that the quality of institutions is lower than in other countries (Figure 7). The indices of the quality of institutions that most closely match the efficiency of collecting taxes are corruption, rule of law, and government effectiveness. These variables are highly correlated among countries in the region and do not differ much within country groups. However, there are large differences across country groups, such as Equatorial Guinea relative to Cape Verde.

The nonresource revenue effort of fiscally dependent resource countries is weaker than for other countries. Because degrees of freedom are limited, the various statutory tax rates enter in separate regressions explaining nonresource revenue. The coefficients on the statutory tax rates for the fiscally dependent countries are lower than for all countries together and lower (10 percent significance) for income taxes (Table 2). To confirm the view that collecting taxes is less efficient in countries with high resource revenue, the corruption index is added to the specification. As foreshadowed, the corruption index is significantly positive in all specifications, and its inclusion lowers the effect of the statutory tax rates on the various revenue categories for the fiscally dependent subsample.$^{8}$ Holding all other elements constant, the difference in the level of corruption between Equatorial Guinea and Cape Verde would lead to a difference of more than 12 percentage points in the non-resource revenue ratio.

\footnotetext{
${ }^{8}$ Similar results hold for rule of law.
} 
Table 2. Effect of Statutory Tax Rates on Nonresource Revenue

\begin{tabular}{|c|c|c|c|c|c|c|c|c|}
\hline Dep. Var: & & & ource ret & lue ratio ${ }^{1 /}$ & & & AT-consur & on ratio ${ }^{21}$ \\
\hline & (1) & $(2)$ & $(3)$ & $(4)$ & (5) & (6) & $(7)$ & (8) \\
\hline VAT rate (all countries) & -0.51 & & & -0.27 & & & -0.03 & 0.07 \\
\hline VAT rate (FD countries) & -0.17 & & & -0.01 & & & -0.16 * & -0.09 \\
\hline Corporate tax rate (all countries) & & -0.38 & & & -0.18 & & & \\
\hline Corporate tax rate (FD countries) & & -0.07 & & & -0.01 & & & \\
\hline Income tax rate (all countries) & & & -0.08 & & & 0.03 & & \\
\hline Income tax rate (FD countries) & & & -0.17 * & & & -0.1 & & \\
\hline Corruption (control of) & & & & 5.71 ** & $5.33^{* *}$ & $6.76^{* * *}$ & & $2.33^{* * *}$ \\
\hline R squared & 0.06 & 0.11 & 0.1 & 0.2 & 0.21 & 0.26 & 0.09 & 0.23 \\
\hline Nobs & 35 & 43 & 38 & 35 & 43 & 38 & 34 & 34 \\
\hline
\end{tabular}

The weaker nonresource revenue effort of fiscally dependent resource countries also holds up for VAT revenue in isolation. A drawback of the empirical specification using all nonresource revenue is that the denominator of the dependent variable (nonresource GDP) does not exactly match the tax base of nonresource revenue, lessening the precision of the test of differences in the statutory tax rate coefficients between resource and nonresource countries. Because information on corporate revenue and wages is not available for SSA countries, it is not possible to get a more precise estimate of the effective corporate or income tax revenue ratio. Indeed, since nonresource revenue may include some resource-related corporate tax revenue, this imparts an upward bias to the coefficient estimates for the resource-rich countries, and therefore the estimated effect is an implicit upper bound on the true relationship between corporate tax rates and nonresource revenue for resource-rich countries.

To circumvent the problem of a revenue mismatch, we use data on total consumption to calculate an effective VAT rate by dividing VAT revenue by total consumption. Replacing the non-resource revenue ratio with the effective VAT rate leads to a significantly weaker coefficient on the statutory VAT rate for fiscally dependent countries compared to all other countries, although its significance vanishes when the corruption index is added to the specification.

This section indicates that it is the effective non-resource tax rate that is lower in resourcerich countries rather than the statutory tax rate. Moreover, the reduced tax effort in resourcerich countries is correlated with the corruption index, so it is possible that the weaker tax effort is associated with the nature of the economy. However, it is also possible that higher 
tax exemptions are playing a role in the weakened tax effort. This is more of a policy choice of resource-rich governments.

\section{CONClusions AND Further Research}

This paper finds evidence suggesting that, controlling for a number of factors, resource exporters in SSA have significantly lower nonresource revenue than other countries in the region, although the strength of the relationship depends on the assumption about the exogeneity of resource revenue. For every 1 percentage point increase in resource revenue as a proportion of GDP, nonresource revenue is lower by about 0.07 to 0.12 percent of GDP. Moreover, after controlling for country-specific factors, the incidence of corruption is associated with a lower ratio of nonresource revenue to GDP, which supports the view that fragile institutions adversely affect the collection of nonresource taxes. Because the statutory tax rates are fairly comparable between resource and nonresource countries, the lower tax take among resource countries is either a choice based on higher tax exemptions/tax holidays or the inability to collect the appropriate revenue effectively as proxied by the corruption index. To distinguish between these hypotheses, it would be useful to gather data on tax exemptions, because this added information would help clarify the need for policy measures to address the revenue shortfall of nonresource revenue among resource-rich countries. This task is left for future work. 


\section{REFERENCES}

Adam, Christopher S., David L. Bevan, and Gerard Chambas, 2000, "Exchange Rate Regimes and Revenue Performance in Sub-Saharan Africa," (United Kingdom: University of Oxford).

Bird, Richard M., 2004, "Managing Tax Reform," Bulletin for International Taxation Vol. 58, No. 2, International Bureau of Fiscal Documentation, (February) pp. 42-55.

Bird, Richard M., Jorge Martinez-Vazquez, and Benno Torgler, 2008, “Tax Effort in Developing Countries and High Income Countries: The Impact of Corruption, Voice and Accountability," Economic Analysis and Policy, Vol 38, No. 1, (March).

Bornhorst, Fabian, Sanjeev Gupta, and John Thornton, 2009, "Natural Resource Endowments and the Domestic Revenue Effort," European Journal of Political Economy, No. 25, pp. 439-446.

Bräutigam, Deborah, 2000, “Aid Dependence and Governance,” Expert Group on Development Issues (Sweden: Almqvist \& Wiksell International).

Collier, Paul, 2005, "Is Aid Oil? An Analysis of Whether Africa Can Absorb More Aid," Centre for the Study of African Economies, (United Kingdom: Oxford University).

Collier, Paul, 2011, "Savings and Investment Decisions in Low-Income Resource Exporters," Centre for the Study of African Economies, (United Kingdom: Oxford University).

Davoodi, Hamid R., and David A. Grigorian, 2007, "Tax Potential vs. Tax Effort: A CrossCountry Analysis of Armenia's Stubbornly Low Tax Collection,” IMF Working Paper 07/106 (Washington: International Monetary Fund).

Drummond, Paulo, Wendell Daal, Nandini Srivastava, and Luiz E. Oliveira, 2012, "Mobilizing Revenue in Sub-Saharan Africa: Empirical Norms and Key Determinants," IMF Working Paper 12/108 (Washington: International Monetary Fund).

Ghura, Daneshwar, 1998, “Tax Revenue in Sub-Saharan Africa: Effects of Economic Policies and Corruption," IMF Working Paper 98/135 (Washington: International Monetary Fund).

Gupta, Abhijit Sen, 2007, "Determinants of Tax Revenue Efforts in Developing Countries," IMF Working Paper 07/184” (Washington: International Monetary Fund).

Gupta, Sanjeev, Benedict Clements, Alexander Pivovarsky, and Erwin R. Tiongson, 2003, "Foreign Aid and Revenue Response: Does the Composition of Aid Matter?" IMF Working Paper 03/176 (Washington: International Monetary Fund). 
International Monetary Fund, 2012, Regional Economic Outlook: Sub-Saharan Africa Chapter 3, (Washington, April).

Leuthold, Jane H., 1991, “Tax Shares in Developing Countries: A Panel Study,” Journal of Development Economics, Vol. 35, pp. 173-185.

Morrison, Kevin M., 2005, “Oil, Non-Tax Revenue, and Regime Stability: The Political Resource Curse Reexamines,” (Duke University, Department of Political Science).

Stotsky, Janet, G., and Asegedech WoldeMariam, 1997, "Tax Effort in Sub-Saharan Africa," IMF Working Paper 97/107, (Washington: International Monetary Fund).

Tanzi, Vito, 1987, "Quantitative Characteristics of the Tax Systems of Developing Countries," in The Theory of Taxation for Developing Countries, ed. by D. Newbery and N. Stern, (United Kingdom: Oxford University Press).

Tanzi, Vito, 1992, "Structural Factors and Tax Revenue in Developing Countries: A Decade of Evidence," in Open Economies: Structural Adjustment and Agriculture, ed. by Ian Goldin and L. Alan Winters (United Kingdom: Cambridge University Press).

Tanzi, Vito, and Hamid Davoodi, 1997, "Corruption, Public Investment and Growth," IMF Working Paper 97/139 (Washington: International Monetary Fund). 